\title{
ポリエチレングリコールラウリルエーテル 水溶液挙動に及ぼすエ夕ノールの影響
}

\author{
松村 美和 $^{* 1}$ - 齊藤 昌子 ${ }^{* 2}$ - 藤居真理子 ${ }^{* 3}$-角田 光雄 ${ }^{* 3}$ \\ *1 共立女子短期大学 ( 101 東京都千代田区一以橋 2-2-1) \\ $* 2$ 共立女子大学 (广101 東京都千代田区一ツ橋 2-2-1) \\ $* 3$ 東京家政学院大学 (T194-02 東京都町田市相原 2600)
}

Effect of Ethanol on the Behavior of Polyethyleneglycol Lauryl Ether in Aqueous Solutions

\author{
Miwa MatsumurA*1, Masako SAito*2, Mariko Fujiı*3, \\ and Teruo TsunOdA ${ }^{* 3}$
}

*1 Kyoritsu Women's Junior College (2-2-1, Hitotsubashi, Chiyoda-ku, Tokyo, ₹101)

*2 Kyoritsu Women's University (2-2-1, Hitotsubashi, Chiyoda-ku, Tokyo, ₹101)

*3 Tokyo Kaseigakuin University (2600 Aihara, Machida-shi, Tokyo, ₹194-02)

\begin{abstract}
Examination was made of the behavior of polyethyleneglycol lauryl ether (nonionic surfactant) in aqueous ethanol solution. Surface tension, penetration power, foaming power, foam stability, viscosity, dynamic surface tension and solubility of lauryl ether with different numbers of P.O.E. concentrations of aqueous ethanol were measured.

From results, the following became apparent. At the air/water interface, lauryl ether forms an absorption film. When ethanol is added to water at $10 \%$, laurly ether begins to dissapear from the surface, and at $20 \%$, surfactant molecules are not present on the surface. At the bulk of the solution, solubility decreased to $1 / 4 \sim 1 / 5$ that of water, indicating that micells to have changed.
\end{abstract}

Key words : polyethyleneglycol lauryl ether, aqueous ethanol solution, solution behavior, absorption film

\section{1 はじめに}

界面活性剂はその特異な物性から種々の用途に用いら れている。界面活性剂の溶液物性に関する研究は, 水溶 液に関するものが多い。溶媒中での物性に関するものに はアルコールに関するものがあるが，アルコール類を用 いた研究では，炭素鎖長の異なるアルコール水溶液中で のアルコール濃度とミセル形成に関するものが多くを占 めている ${ }^{1) \sim 9) 。 ~}$

筆者らはこれまで，フロン代替溶剤としてのエタノー ル水溶液が持つ洗浄性能について調べ，エ夕ノール水溶 液に界面活性剂を添加した時の洗浄性の変化と界面活性 剂の構造との関係などについて報告してきた ${ }^{10) \sim 18) 。 ~}$

連絡者: 齊藤昌子
これらの中で, エタノール濃度が低い場合には, 界面活 性剂の添加が洗浄性能に大きく寄与し, その効果は界面 活性剤の構造に大きく依存することをこれまでの研究で 明らかにしてきた。

本研究では, このような洗浄性の違いを解明するため に, エ夕ノール水溶液中における界面活性剂の挙動を明 らかにしようとした。本研究では界面活性剂として非イ オン系のポリエチレングリコールラウリルエーテル（以 下ラウリルエーテルと略) を用い, POE 付加モル数の 異なるラウリルエーテルのエタノール水溶液について, 表面張力, 起泡力, 表面粘弾性, 動的表面張力, 可溶化 量を測定し, 溶液物性を明らかにした。

\section{2 試 料}

界面活性剂には Table 1 に示す 4 種のラウリルエー 
Table 1 Sample.

\begin{tabular}{l|l|c|c|c}
\hline \multicolumn{1}{c|}{ Sample } & \multicolumn{1}{c|}{ Structure } & Abbreviation & HLB & Purity \\
\hline $\begin{array}{l}\text { Tetraethyleneglycol } \\
\text { lauryl ether }\end{array}$ & $\begin{array}{l}\mathrm{C}_{12} \mathrm{H}_{25}\left(\mathrm{CH}_{2} \mathrm{CH}_{2} \mathrm{O}\right)_{4} \mathrm{OH} \\
(\mathrm{m} . \mathrm{w} .342)\end{array}$ & $\mathrm{C}_{12} \mathrm{H}_{4}$ & 10.2 & $98 \%$ \\
\hline $\begin{array}{l}\text { Hexaethyleneglycol } \\
\text { lauryl ether }\end{array}$ & $\begin{array}{l}\mathrm{C}_{12} \mathrm{H}_{25}\left(\mathrm{CH}_{2} \mathrm{CH}_{2} \mathrm{O}\right)_{6} \mathrm{OH} \\
(\mathrm{m} . \mathrm{w} .430)\end{array}$ & $\mathrm{C}_{12} \mathrm{H}_{6}$ & 12.3 & $98 \%$ \\
\hline $\begin{array}{l}\text { Octaethyleneglycol } \\
\text { lauryl ether }\end{array}$ & $\begin{array}{l}\mathrm{C}_{12} \mathrm{H}_{25}\left(\mathrm{CH}_{2} \mathrm{CH}_{2} \mathrm{O}\right)_{8} \mathrm{OH} \\
(\mathrm{m} . \mathrm{w} .518)\end{array}$ & $\mathrm{C}_{12} \mathrm{H}_{8}$ & 13.6 & $98 \%$ \\
\hline $\begin{array}{l}\text { Decaethyleneglycol } \\
\text { lauryl ether }\end{array}$ & $\begin{array}{l}\mathrm{C}_{12} \mathrm{H}_{25}\left(\mathrm{CH}_{2} \mathrm{CH}_{2} \mathrm{O}\right)_{10} \mathrm{OH} \\
(\mathrm{m} . \mathrm{w} .606)\end{array}$ & $\mathrm{C}_{12} \mathrm{H}_{10}$ & 14.5 & $98 \%$ \\
\hline
\end{tabular}

テルを用いた。これらの試料はすべて日光ケミカルズ社 製のもので，純度 $98 \%$ 以上のもである。

\section{3 実 験方法}

4 種のラウリルエーテルの, 比率の異なるエタノール 水溶液（エ夕ノール 0 60\%）中における下記の測定を 行った。エ夕ノール水溶液におけるエタノールの比率は すべて容量比率とした。

1）表面張力

ウィルヘルミー法（島津 ST-1 型使用）を用いて測定 した。測定温度 $20 \pm 2^{\circ} \mathrm{C}$ とし, 3 回の平均値をとった。

2) 浸透力

ドレーブス改良法を用いて測定した。試料布は $3 \mathrm{~cm}$ $\times 10 \mathrm{~cm}$ の毛を用いた。沈降するまでの時間 $(\mathrm{s})$ を 3 回測定し平均值をとった。

3）起泡力と泡の安定性

簡易ロス・マイルス法を用いて測定した。 $30 \mathrm{~mL} の$ 共栓付き試験管に $10 \mathrm{~mL}$ の試料溶液を入れ，栓まで届 く強さに 20 回振り, $1 \mathrm{~min}$ ごとに泡の高さを測定し た。界面活性剂濃度は $0.001 \%$ とし，(1 min 後の高さ /5 min 後の高さ) を泡の安定性の指標とした。

\section{4）表面粘弾性}

減衰振動法（協和界面科学表面粘弾性計 SVR-1 使 用）を用いて測定した。この方法は，試料表面に接した 円盤を回転させ，円艋の回転が減衰していく際の自然減 衰率，および水の減衰率などから，式 (1) を用いて算出 するものである。

$$
\begin{array}{ll}
\mathrm{n}^{\mathrm{S}}= & \frac{2.303 I}{2 \pi}\left(\frac{\lambda_{10}}{\tau}-\frac{\lambda_{10 \mathrm{w}}}{\tau_{\mathrm{w}}}\right)\left(\frac{1}{r_{1}{ }^{2}}-\frac{1}{r_{2}{ }^{2}}\right) \\
I \quad: \text { 慣性モーメント } \\
\tau \quad: \text { 振動の周期 } \\
\tau_{\mathrm{w}}: \text { 水の振動の周期 } \\
\lambda_{10}: \text { 振幅の自然対数減衰率 } \\
\lambda_{10 \mathrm{w}}: \text { 水の振幅の自然対数減衰率 } \\
r_{1} \quad: \text { 円盤の半径 } \\
r_{2} \quad: \text { シャーレの半径 }
\end{array}
$$

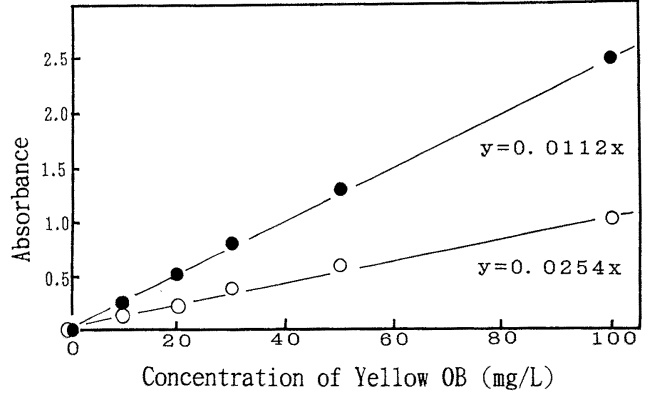

Fig. 1 Calibration Curve of Yellow OB, $(O)$; Water, (๑) ; EtOH 10\%.

予備実験の結果から, 試料表面を清掃してから測定す るまでの時間が結果に大きく影響を及ぼすことが判明し たので, 測定に当たっては, 值が一定となる $5 \mathrm{~min}$ 後 の値を採用した。測定温度は $22 \pm 3^{\circ} \mathrm{C}$ とした。

5）動的表面張力

表面積変化法（協和界面科学自動動的表面張力計 DST-A1 型使用）を用いて測定した。界面活性剂濃度 は $0.001 \%$ とした。

6) 可溶化量

水およびエ夕ノール $10 \%$ における $\mathrm{C}_{12} \mathrm{E}_{10}$ の油溶性 染料 (Oil Yellow OB) の可溶化量を測定した。界面活 性剂濃度は，水 $100 \%$ では, $7.7 \times 10^{-5}, 1.5 \times 10^{-4}, 3.1$ $\times 10^{-4} \mathrm{M}$, エタノール $10 \%$ では, $4.3 \times 10^{-5}, 1.5 \times 10^{-5}$, $1.7 \times 10^{-4} \mathrm{M}$ とした。

試料溶液に過剩の Oil Yellow OB を加え, $25^{\circ} \mathrm{C} て ゙ ~ 13$ $\mathrm{h}$ 振とう後沃過し, 沃液の $440 \mathrm{~nm}$ における吸光度から 検量線を用いて可溶化量を算出した。Oil Yellow OB の検量線を Fig. 1 に示した。

\section{4 結果と考察}

\section{$4 \cdot 1$ 表面張力}

測定結果を Fig. 2 に示した。

表面張力は, $\mathrm{POE}$ 付加モル数の小さい $\mathrm{C}_{12} \mathrm{E}_{4}, \mathrm{C}_{12} \mathrm{E}_{6}$ 

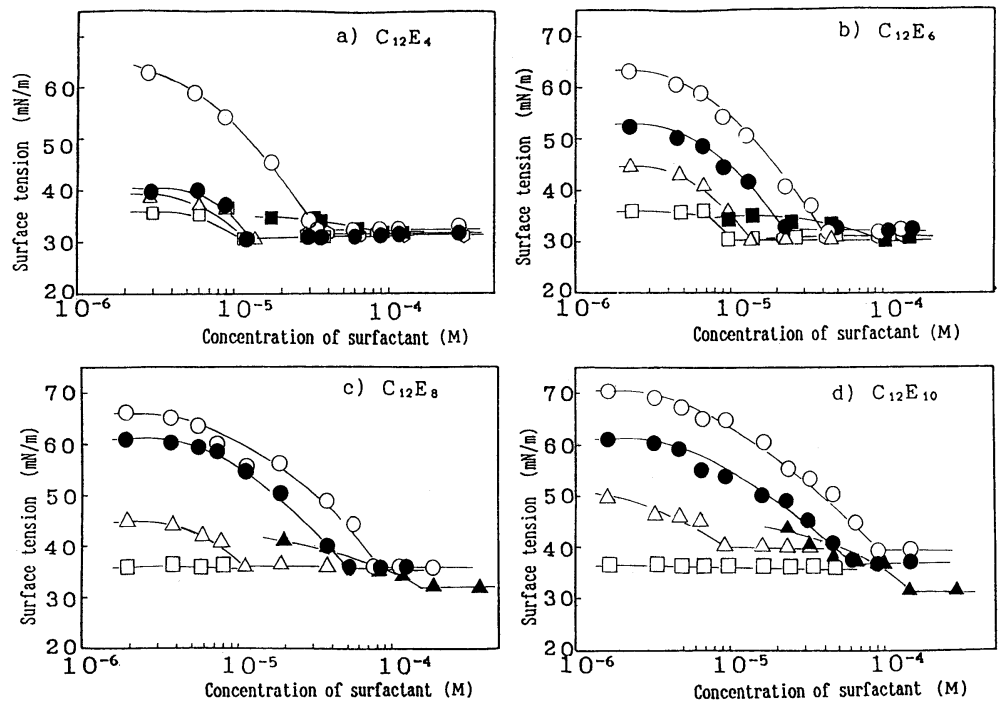

Fig. 2 Surface Tension of Ethyleneglycol Lauryl Ether in the Different Aqueous

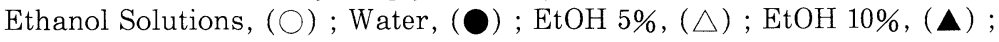

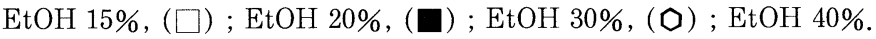

ではエタノール濃度 $20 \%$ までは濃度の増加とともに低 下し, cmc も低濃度側に移行した。しかし, エタノー ル $30 \%$ では $\mathrm{cmc}$ は高濃度側へ移行し, 水溶液より大き い值となり，40\%では $\mathrm{cmc}$ は消失した。 $\mathrm{C}_{12} \mathrm{E}_{8}, \mathrm{C}_{12} \mathrm{E}_{10}$ では, エ夕ノール $10 \%$ までは $\mathrm{cmc}$ が低濃度側へ移行し たが，15\%では逆に高濃度側へ増大した後，20\%では $\mathrm{cmc}$ が消失した。

Nishikido ら ${ }^{1}$ は, ラウリルエーテル (POE 付加モ ル数 : $6,11,20,31)$ を用いて比率の異なるアルコール 水溶液 (メタノール, エタノール, プロパノール, ブタ ノール, ペンタノール) の $\mathrm{cmc}$ を測定している。 $\mathrm{C}_{12}$ $\mathrm{E}_{6}$ のメタノール, エタノール水溶液では, $\mathrm{cmc}$ は増大 し, プロパノールでは減少した後増大, ブタノール, ペ ンタノールでは減少したとしている。また, $\mathrm{C}_{12} \mathrm{E}_{31}$ で はメタノール, エタノール水溶液の $\mathrm{cmc}$ は $\mathrm{C}_{12} \mathrm{E}_{6}$ と同 じく増大するが, プロパノール, ブタノール, ペンタ ノールでは減少した, プロパノールの結果はイオン性界 面活性剂の結果と一致したと報告している。本研究の結 果は Nishikido らの結果とは一致しなかった。

エタノール濃度による $\mathrm{cmc}$ の変化については, SDS について Shirahama ${ }^{8)}$ と Singh ${ }^{9)}$ が, TTAB につい てZana ${ }^{6)}$ が, DDAB について Sela ${ }^{3)}$ が, 測定してい るが，いずれもエタノール濃度の増大による $\mathrm{cmc}$ の極 小值の存在を報告している。これらの一連の研究結果か ら, Zana ${ }^{7)}$ も述べている通り, エタノールがアルコー ルの中で cmc 増減のボーダーラインにあることは明ら かである。本研究と Nishikido らの結果との不一致 は, 用いた界面活性羭の純度によるのではないかと考え
た。また, cmc の消失した溶液表面では, 界面活性剂 分子は存在せず, エ夕ノール分子が表面を覆っているこ とを示唆していると考察した。

\section{$4 \cdot 2$ 浸透力}

測定結果を Fig. 3 に示した。浸透力は水溶液におい
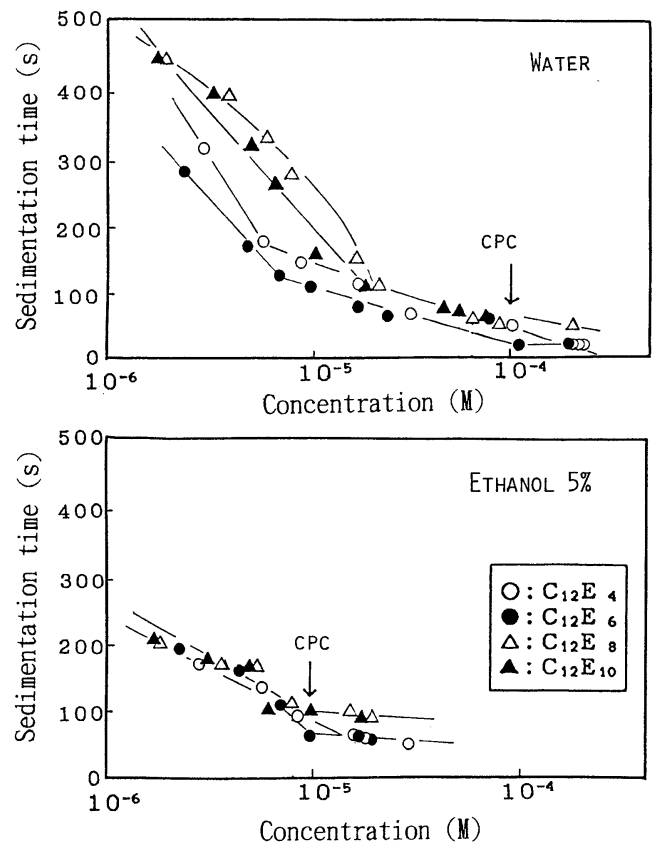

Fig. 3 Penetration Power of Ethyleneglycol Lauryl Ether in Water and in 5\% Aqueous Ethanol Solution. 
ては POE 付加モル数による違いが見られたが，エ夕 ノール 5\% では浸透力が大きく，その違いはほとんど見 られなくなった。このことから，エタノール5\%ではラ

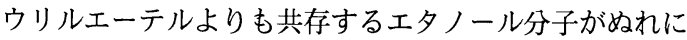
大きく関与していることがわかった。沈降時間が一定に なるときの界面活性剂濃度を臨界浸透力濃度 $(\mathrm{cpc})$ と 名づけた。 $\mathrm{cpc}$ は水溶液においても，エ夕ノール $5 \%$ に おいても表面張力の大きさに関係なくほぼ一定の濃度に あることがわかった。その濃度は，水溶液においては 1 $\times 10^{-4} \mathrm{M}$ に，エタノール $5 \%$ では $1 \times 10^{-5} \mathrm{M}$ 付近に存 在し, エタノール $5 \%$ の $\mathrm{cpc}$ が水溶液より低濃度側に ある。これらのことから，溶液中に存在する界面活性剂 ならびにエ夕ノールの分子数が沈降時間を決定づけてい ることがわかった。

\section{$4 \cdot 3$ 起泡力と泡の安定性}

測定結果を Fig. 4〜7に示した。起泡力はエタノール 10\% において極大值を示した (Fig. 4)。また POE 付 加モル数が大きい程起泡力は大きく, その傾向はエ夕 ノール10\%でもっとも顕著であった (Fig. 5)。この結 果から，エ夕ノールが入ることによって気泡の気液界面 における吸着膜の強度が大きくなり,さらにエ夕ノール

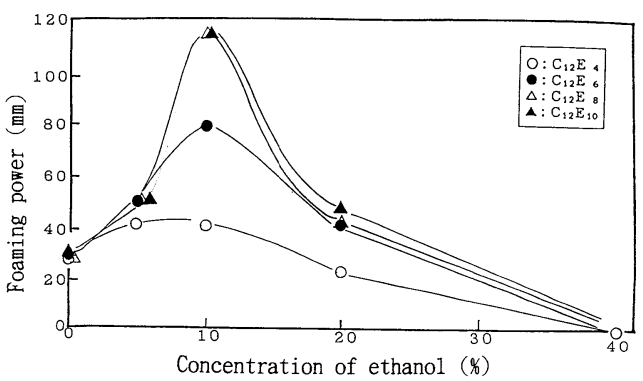

Fig. 4 Foaming Power of Ethyleneglycol Lauryl Ether in the Different Ethanol Concentrations.

Concentration of surfactant ; $1 \times 10^{-3} \%$.

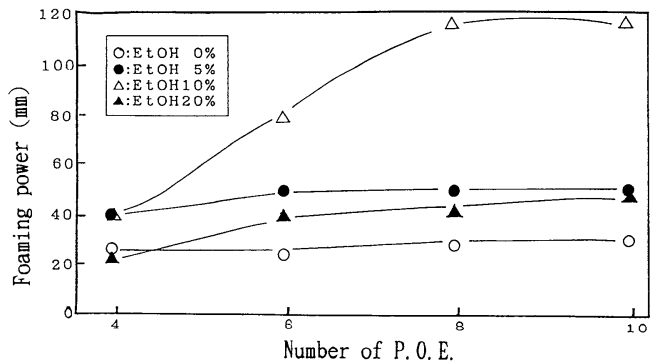

Fig. 5 Relations between the Foaming Power and the Number of POE of Ethyleneglycol Lauryl Ether.

Concentration of surfactant; $1 \times 10^{-3} \%$.

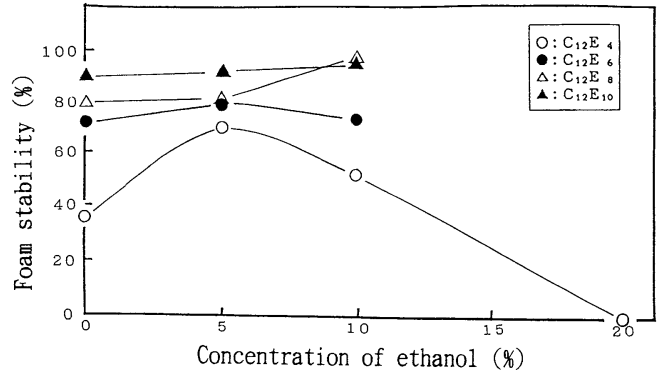

Fig. 6 Foam Stability of Ethyleneglycol Lauryl Ether in the Different Ethanol Concentrations.

Concentration of surfactant ; $1 \times 10^{-3} \%$.

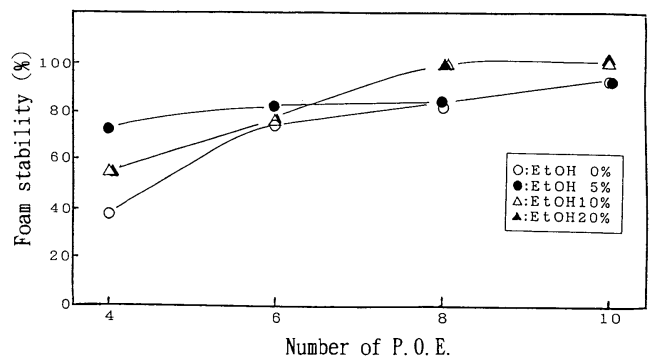

Fig. 7 Relations between the Foam Stability and the Number of POE of Ethyleneglycol Lauryl Ether.

Concentration of surfactant; $1 \times 10^{-3} \%$.

の量が増加すると逆に強度は低下し，エタノール $40 \%$ では界面活性剂の界面活性能は失われ，気液界面には界 面活性剂の吸着膜はほとんど存在せず，エ夕ノール分子 のみであると推察した。

泡の安定性には起泡力にみられたような大きな変化は 見られなかった (Fig. 6)。POE 付加モル数が大きいほ ど安定性はよいが (Fig. 7), エ夕ノール濃度による違い は小さい。これは，一たんできた泡では配列した界面活 性剤膜がその安定性を支配し，エ夕ノール分子の有無よ りもむしろ POE 付加モル数が大きい影響を与えること を示唆している。POE 4 と 6 以上での違いは, 6 以上の 方が気液界面への配列の安定性が大きいためと考えられ る。

\section{$4 \cdot 4$ 表面粘弾性}

結果を Fig. 8 に示した。 $\mathrm{C}_{12} \mathrm{E}_{10}$ の表面ずり粘性率は エタノール $10 \%$ で最大值を示し，エタノール濃度が大 きくても小さくても粘性率は小さくなることがわかっ た。この結果は, 起泡力の結果とよく一致した (Fig. 8)。このことから，エタノールの添加により界面活性剂 溶液の粘性が増大し, 泡膜の強度か増した結果, 起泡力 が増大したものと思われる。さらにエタノールの量が増 


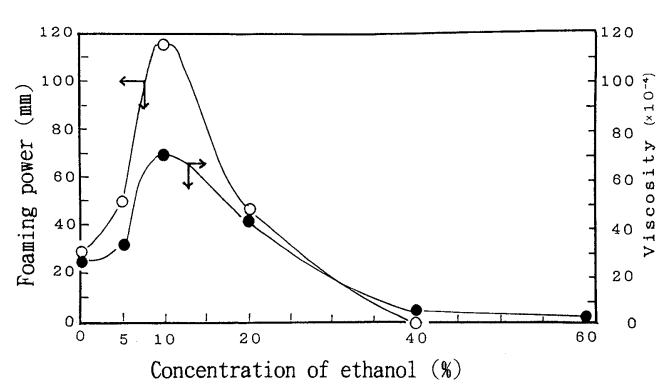

Fig. 8 Viscosity and Foaming Power of Decaethyleneglycol Lauryl Ether $\left(\mathrm{C}_{12} \mathrm{E}_{10}\right)$ in the Different Aqueous Ethanol Solutions. $(\bigcirc)$; Foaming power, (O) ; Viscosity.

加すると, 気液界面における界面活性剂の割合が減少 し, 粘性が減少すると同時に起泡力も急激に低下したと 推察した。

\section{$4 \cdot 5$ 動的表面張力}

測定結果を Fig. 9 に示した。動的表面張力から得ら れる試料表面の表面エネルギー変化はエタノール濃度の 増加とともに直線的に減少した。動的表面張力は, 試料 表面に存在する分子を清掃したときにどの程度の早さで 新たな分子が表面に補われるかを示すものであり, 界面 活性剂の Maragoni 効果 ${ }^{19)}$ として知られている。今回 の結果は, 試料表面に存在する界面活性剤分子の量が水 溶液表面で最も多く, エ夕ノールが増加するに従い減少 していることを示唆しており, エ夕ノールの添加によ り, 表面に存在したラウリルエーテル分子は表面から溶 液内部へ潜り込み, エ夕ノール分子が表面に多く存在す るのではないかと考察した。

\section{$4 \cdot 6$ 可溶化量}

測定結果を Fig. 10 に示した。Yellow OB の可溶化 量は水溶液では濃度とともに大きく増加したが, エ夕 ノール $10 \%$ では増加は小さく, しかも水溶液のおよそ 1/4〜1/5であった。

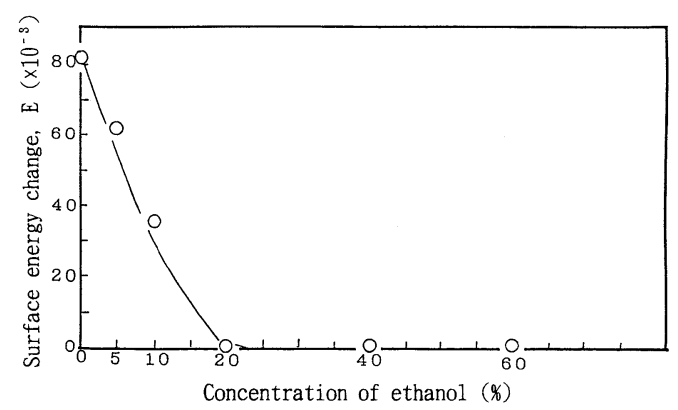

Fig. 9 Dynamic Surface Tension of Decaethyleneglycol Lauryl Ether $\left(\mathrm{C}_{12} \mathrm{E}_{10}\right)$.

Concentration of surfactant ; $1 \times 10^{-4} \%$.

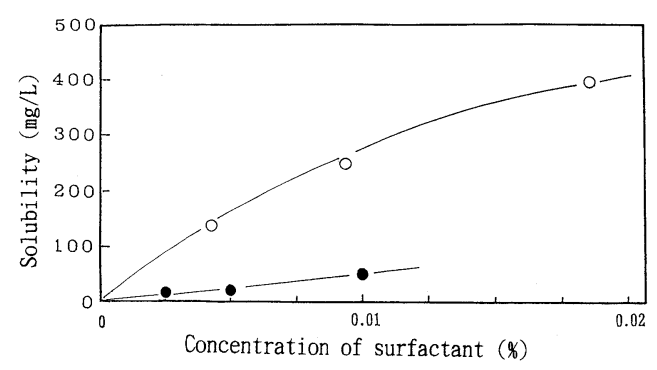

Fig. 10 Solubility Power of Decaethyleneglycol Lauryl Ether $\left(\mathrm{C}_{12} \mathrm{E}_{10}\right)$ in Water and $10 \%$ Aqueous Ethanol Solution.

(○) ; Water, (O) ; EtOH 10\%.

\section{5 ラウリルエーテルのエタノール水溶液中に おける挙動}

得られた結果からラウリルエーテルのエタノール水溶 液中における挙動を下記のように推察した。

ラウリルエーテル分子は, 水溶液表面では吸着膜を形 成して表面張力を低下している (Fig. 11a)。低下の程 度は POE 付加モル数の小さいものほど大きい。ラウリ ルエーテル水溶液にエタノールが添加されると, エ夕 ノール分子の一部はラウリルエーテル吸着膜の間に入り 込み (Fig. 11b), 徐々にラウリルエーテル分子を表面か ら追放する結果, ラウリルエーテル分子は溶液内部へ潜 り込む。エタノール分子の入り込んだ吸着膜は強度を増 し, エタノール濃度 $10 \%$ 付近で膜の強度は最大となる

a) Water

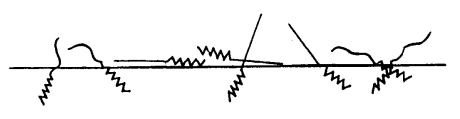

b) Ethanol $5 \%$
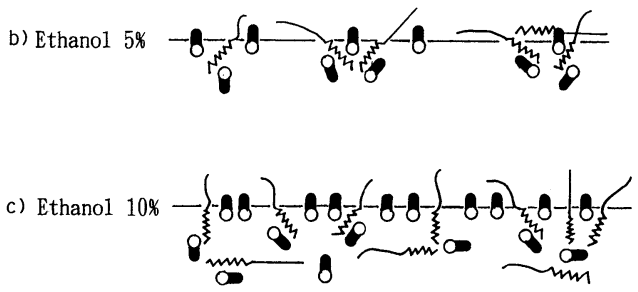

d) Ethanol $20 \%$

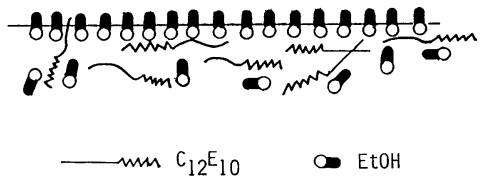

Fig. 11 Behavior of Decaethyleneglycol Lauryl Ether $\left(\mathrm{C}_{12} \mathrm{E}_{10}\right)$ at the Water/Air Interface in the Different Aqueous Ethanol Solutions. 
(Fig. 11c)。溶液内部へのラウリルエーテルの潜り込み は POE 付加モル数の大きい, 親水性の大きいものほど 大きい。エ夕ノール濃度 $20 \%$ では, 溶液表面には界面 活性剤分子は存在しない (Fig. 11d)。

\section{6 結 論}

非イオン系界面活性剤であるポリエチレングリコール ラウリルエーテルのエタノール水溶液中における挙動を 調べた。POE 付加モル数の異なるラウリルエーテルが 比率の異なるエ夕ノール水溶液中でどのような挙動を示 すかについて, 表面張力, 浸透力, 起泡力と泡の安定 性，表面粘弾性，動的表面張力，可溶化量について調べ た結果，ラウリルエーテルの挙動は水溶液の場合とは大 きく異なった。

エ夕ノール水溶液ではエ夕ノールの比率が $10 \%$ を越 えるころから，ラウリルエーテルは液中に潜りこみ始 め, $20 \%$ 付近では溶液表面には界面活性剂分子は存在 しないことが推察された。溶液内部では，可溶化量が 1/4 1/5 程度に減少し，ミセルの状態が水溶液中とは 異なることが推察された。ミセルの状態については, 現 在検討中である。

謝辞 : 本研究を行うに当たり，実験装置の使用を許可さ れた協和界面科学株式会社に感謝の意を表しま す。

（受付： 1995 年 11 月 15 日, 受理 : 1996 年 4 月 23 日）

\section{文献}

1) N. Nishikido, Y. Moroi, H. Uehara, R. Matsuura, Bull. Chem. Soc. Jpn ., 47, 2634 (1974).

2) I.V. Rao, E. Ruckensten, J. Colloid Interface Sci., 113, 375 (1986)

3) Y. Sela, S. Nagdassi, Tenside Surf. Det., 28, 137 (1991).
4) 吉岡康司, 長田隆博, 広中清一郎, 油化学, 206, 40 (1991).

5) S. Lamparski, J. Colloid Interface Sci., 144, 153 (1991).

6) R. Zana, S. Yiv, C. Strazielle, P. Lianos, J. Colloid Interface Sci., 80, 208 (1981).

7) R. Zana, Adv. Colloid Interface Sci., 57, 1 (1995).

8) K. Shirahama, T. Kashiwabara, J. Colloid Interface Sci. , 36, 65 (1971).

9) H.N. Singh, S. Swarup, Bull. Chem. Soc. Jpn., 51, 1534 (1978).

10）齊藤昌子, 高橋兆子, 藤居真理子, 角田光雄, 第 23 回 洗浄に関するシンポジウム要旨集，p. $67,73 ， 79,85$, (1991).

11）松村美和，齊藤昌子，高橋兆子，藤居真理子，角田光 雄, 第 24 回洗浄に関するシンポジウム要旨集, p. 83, (1992).

12）中村展子, 高橋兆子, 藤居真理子, 角田光雄, 齊藤昌 子, 第 24 回洗浄に関するシンポジウム要旨集, p. 89, (1992).

13）藤居真理子, 高橋兆子, 中村展子, 角田光雄, 齊藤昌 子, 第 24 回洗浄に関するシンポジウム要旨集, p. 95, (1992).

14）高橋兆子, 藤居真理子, 中村展子, 角田光雄, 齊藤昌 子, 第 24 回洗浄に関するシンポジウム要旨集, p. 102, (1992).

15）角田光雄, 高橋兆子, 藤居真理子, 齊藤昌子, 小林光 一, 谷口寿保, 中島嘉之, 第 24 回洗浄に関するシンポ ジウム要旨集, p. 108, (1992)

16）角田光雄, 藤居真理子, 高橋兆子, 中村展子, 齊藤昌 子, 第 25 回洗浄に関するシンポジウム要旨集, p. 79, (1993).

17) T. Tsunoda, M. Fujii, C. Takahashi, N. Nakamura, M. Saito, 第 25 回洗浄に関するシンポジウム要旨 集, p. 127 (1994).

18) T. Tsunoda, M. Fujii, C. Takahashi, N. Nakamu$\mathrm{ra}, \mathrm{M}$. Saito, Proceedings of the 12 th International Symposium on Contamination Control, Oct. 10-14, 1994, Yokohama.

19）佐々木恒孝, “界面現象の基礎”, 朝倉書店 (1973) p 184. 
を起こすときの臨界温度 $\left(\mathrm{T}^{*}\right)$ として理解された。

温度 $\mathrm{T}^{*}$ が高次の相転移をする臨界温度であることは測定した $\mathrm{C}_{\mathrm{pL}}$ のデーターから決定された。すなわち， $\mathrm{C}_{\mathrm{pL}}$ が 平衡値に到達するまでに要する時間の温度変化と温度差の逆数 $\left(\mathrm{T}^{*} \text { - } \mathrm{T}\right)^{-1}$ のプロットは $28.60{ }^{\circ} \mathrm{C}$ と

2 8. $96{ }^{\circ} \mathrm{C}$ 間で急激に増大した。しかし， T> T*では急激にこの緩慢現象は見られなかった。 $\mathrm{T} *$ 近傍での このような緩慢現象は高次相転移を示す系では一般的な特徴である。高次相転移の温度領域で熱力学バラメ夕一を $\mathrm{C}_{\mathrm{pL}} \sim \mathrm{T}$ 曲線から算出した。その結果, 転移のエンタルピー変化は $3.43 \mathrm{~J} / \mathrm{mol} 1$ または二分子膜の単位面積

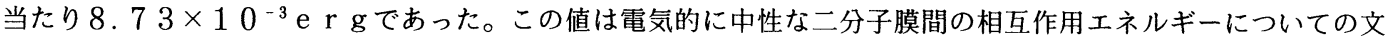
献値と一致した。本研究で新しく得られた転移の動的性質と二分子膜の安定性とを関連ずけて議論をした。

（連絡者:田嶋和夫）Vol. 45, No. 7, 647 (1996).

\section{[報文] シリカぶルカラムを用した超臨界クロマト グラフィーに抢ける非イオン性化合物の溶出挙動と ステップグラジェント分画}

五十嵐 章 紀 - 田中幸子、田中正一 - 堀口恭伸 ライオン株式会社研究開発本部分析センター（テ132 東京都江戸川区平井7-13-12）

シリカゲルカラムを用いた超臨界流体クロマトグラフィー（ＳＦＣ）における，いくつかの極性ないし非極性化 合物の溶出挙動を検討した。薄層クロマトグラフィーにおいて, 理論式; [ $\left.1 \circ \mathrm{g} \mathrm{k}{ }^{\prime}=\alpha\left(\mathrm{S}^{0}-\mathrm{As}_{\mathrm{s}} \mathrm{X} \varepsilon^{0}\right)+\mathrm{C}\right]$ として報告されている関係, すなわち, 容量係数 $\left(\mathrm{k}^{\prime}\right)$, 吸着エネルギー $(\mathrm{S})$, 吸着断面積 $\left(\mathrm{A}_{\mathrm{s}}\right)$ 及び溶媒強度 $\left(\varepsilon^{0}\right)$ の間の関係式が，われわれが行った S F C の条件下でも成立することが分かった（Cはカラム定数， $\alpha$ はシ リカゲルカラムの活性化度である）。この結果から, 個々の化合物の溶出時間は予測が可能であり，モディファイ ヤーの種類と濃度を適切に選ぶことにより，クロマトグラフ条件が容易に設定できることが示唆された。本法を香 粧品及び化粧品に用いられる成分の混合物の, ステップグラジエントモード分画に応用した。炭化水素, 脂肪アル コール，アルキルグリセリルエーテル，脂肪酸モノエタノールアミド，脂肪酸ジエタノールアミドが良好に分画で きた。 （連絡者:五十嵐章紀）Vo1. 45, No. 7, 655 (1996).

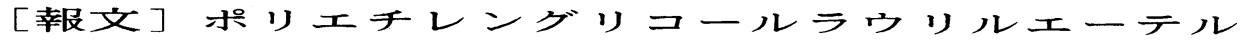

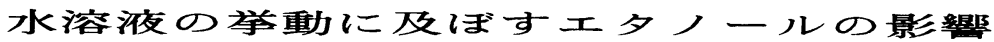

松村美和 $* 1$ - 斎藤昌子 $* 2$ - 藤居真理子 $* 3$ - 角田光雄 $* 3$

*1 共立女子短期大学 (下101 東京都千代田区一ツ橋2-2-1）

*2 共立女子大学 （i101 東京都千代田区一ツ橋2-2-1）

*3 東京家政学院大学（元194-02東京都町田市相原2600）

非イオン系界面活性剂であるポリエチレングリコールラウリルエーテルのエタノール水溶液中における挙動を明 らかにした。P O E 付加モル数の異なるラウリルエーテルの, 比率の異なるエタノール水溶液中における表面張力, 浸透力, 起泡力, 泡の安定性, 表面粘弾性, 動的表面張力, 可溶化量を測定した。これらの結果から, 水溶液表面 ではラウリルエーテル分子が吸着配向し膜を形成しているのに対し，エタノール水溶液表面ではエ夕ノールの比率 が $10 \%$ を越える頃からラウリルエーテル分子が液中に潜り込み始め, $20 \%$ 付近では活性剤分子は表面には存在 しないことが推察された。溶液内部では, 可溶化量が 4 分の 1 〜分の 1 程度に減少し, ミセルの状態が変化した ことが推察された。

(連絡者:斎藤昌子) Vo1. 45, No. 7, 661 (1996). 